\title{
Terpsichorean Architecture: Editor’s Introduction
}

\section{Tony Mitchell, University of Technology Sydney}

In Peter Hoeg’s celebrated novel Miss Smilla’s Feeling for Snow (1992), Greenlandborn Smilla says of her extraordinary ability to decipher patterns and read tracks in snow: 'Reading snow is like listening to music. To describe what you've read is to try and describe music in writing' (2005:37). Later in the book, Andreas Fine Licht, a blind Professsor of Eskimo Languages and Cultures at the Danish Institute of Eskimology, deciphers a tape recording of a native Greenlander speaking in dialect about hunting. He is also able to hear and identify in the background on the tape the jazz music of trumpeter Roy Louber, formerly of the John Coltrane quartet, in a rare live concert performance in Thule in the late 1960s (2005:134). The experience of listening to, or hearing and identifying music may, in both cases, be a complex one, but writing about it comprehensively and memorably can be even more complex and fraught with difficulties.

This selection of papers comes from a Symposium held at the University of Technology Sydeny (UTS) in September 2009. The title derives from a notorious quote-now a cliché-from Elvis Costello in an interview in the British Musician magazine in 1983: 'Writing about music is like dancing about architecture-it's a really stupid thing to want to do' (White 1983). It has been attributed by various people at various times to Frank Zappa, Thelonious Monk, Laurie Anderson, David Byrne and numerous others, 
while Costello and others have attributed it to Martin Mull, possibly in 1979, although an exact source has never been found. ${ }^{1}$

Apart from tipping my hat to Martin Mull, a long neglected satirical singer-songwriter in the vein of Randy Newman, who once opened for Zappa in Austin, Texas, in 1973, and whose music I particularly enjoyed in the 1970s, before he turned to film, television and painting, it would appear that Costello, whether he likes it or not, has to live with the attribution. Zappa actually said of the rock music press, arguably with some degree of accuracy, at least for anyone who reads the weekly music street press: 'Most rock journalism is people who can't write, interviewing people who can't talk, for people who can't read' (cited in Botts 1981: 74 ).

In his monograph on Costello, Dai Griffiths takes the quotation seriously, beginning a chapter entitled 'Criticism' with the claim that it 'is a fine analogy for the purposelessness of writing about music.' Griffiths even invokes the Abbé du Bos’s 1719 Réflexions critiques sur la poésie et sur la peinture from Wimsatt and Brooks's history of criticism, and examines various poetry anthologies, before getting down to the more mundane business of assessing reviews of Costello's albums and performances from the British weekly music press (2008: 115). David Brackett likewise takes the statement seriously. Concluding his book Interpreting Popular Music with a 40-page chapter analysing Costello’s song 'Pills and Soap,' from his 1983 album Punch the Clock, he deems it necessary to 'consider the implications of this statement-which could be interpreted as a dismissal of the entire project of this book' (2000: 157). Brackett interprets the statement as pointing to the 'untranslatability of one art form to another,' and notes that Costello is contradicting himself in agreeing to the interview in which he makes the statement in the first place, and is speaking in the context of responding to a question about harassment by the music press. Brackett suggests that Costello may be claiming that 'analysing an art form is antithetical to producing art,' an anti-intellectual position that regards art as spontaneous and that 'thinking about it too much will interrupt the flow of inspiration' (158). He then quotes a 1994 interview where Costello contradicts this apparent separation between technique and inspiration. Brackett goes on to suggest that this 'tension between calculation and spontaneity' (or musicology and inspiration) is typical not only of 'somewhat marginal' musicians like Costello but also

\footnotetext{
${ }^{1}$ As I discovered from Quoteinvestigator.com: http:/quoteinvestigator.com/2010/11/08/writing-aboutmusic/.
} 
of the popular music industry in general. He then proceeds to situate Costello, via Bourdieu, in a context of 'intellectual pop music' (160). This is a feasible claim, especially given Costello’s 2008-2010 television program Spectacle: Elvis Costello with ... where, clipboard in hand, as songwriter-critic, he interrogates US songwriters such as Allen Toussaint, John Prine and Bruce Springsteen about their song writing, and asks them to sing a particular song that illustrates their techniques.

New Yorker music critic Alex Ross begins his 2010 collection of essays Listen to This by blithely and cavalierly brushing aside Costello’s alleged statement:

\begin{abstract}
Writing about music isn’t especially difficult. Whoever coined the epigram ... was muddying the waters. Certainly, music criticism is a curious and dubious science, its jargon ranging from the wooden ... to the purple. But it is no more dubious than any other kind of criticism. Every art form fights the noose of verbal description. Writing about dance is like singing about architecture; writing about writing is like making buildings about ballet. There is a fog-enshrouded border past which language cannot go. ... In my writing on music, I try to demystify the art to some extent, dispel the hocus-pocus, while still respecting the boundless human complexity that gives it life. (Ross 2010: xi-xii)
\end{abstract}

This sounds suspiciously like bombast. Ross goes on to claim that '[t]he difficult thing about music writing, in the end, is not to describe a sound but to describe a human being' (xiii). This suggests that he may be confusing writing about music with music biography, where a musician or composer's career provides the context in which a critique of their music is made. In his essays on Bob Dylan, Radiohead, Björk, and Kurt Cobain, all of which verge on hagiography, Ross appears to fall into this trap, even if his musical knowledge is sounder than that of most music writers. Reviewing Listen to This in the Sydney Morning Herald, classical music writer John Carmody describes Ross’s forays into pop music as 'little more than uncritical fan-club gush,' and concludes: 'Ross plainly wants to think that, as a New Yorker chap, he's a man about town, au fait with the latest and most chic trends yet, apart from a PR-style chapter on John Luther Adams, he writes dismayingly little about contemporary concert music’ (Carmody 2011: 30).

It was as an expert on 'contemporary concert music' in the $20^{\text {th }}$ century, on the strength of his previous book The Rest is Noise (2007), an award-winning best seller, that Ross was invited to 'curate and present' a concert program and do a speaking tour with the Australian Chamber Orchestra in 2011. The ACO likes to refer to itself as a 'renegade' in the classical music world, and its publicity includes a quote from Time Out New York 
describing them as a 'badass classical band' (Shades of Nigel Kennedy). Nonetheless, although often contemporary, their programs tend to be rather conservative, and the works that Ross chose by and large fitted that bill: Takemitsu's Nostalghia, Britten's Variations on a Theme of Frank Bridge, Stravinsky's Apollo: Apotheosis, Webern's Five Movements, Op.5, Xenakis’ Voile, and Richard Strauss’s Metamorphosen. Nothing here that Theodor Adorno would have disapproved of, or that regular Sydney concertgoers wouldn’t have experienced before.

My purpose in using the title 'Terpsichorean Architecture' was, in fact, to turn the supposedly oppositional binarism of Costello's statement on its head, and suggest that, far from being 'a really stupid thing to want to do,' writing about music is a vitally important activity. It can not only communicate the seemingly incommunicable, but can convey what are always subjective impressions to a readership seeking ways of understanding and relating to different forms and genres of music. The Symposium concluded with a round table discussion between musicians and music critics: Lloyd Swanton of internationally successful Sydney jazz-improvisation group the Necks, Hollis Taylor, composer, violinist, and ornithologist, and also the music critics, Bernard Zuel, rock and pop music reviewer for the Sydney Morning Herald, and John Shand, jazz reviewer for the same newspaper. As an admirer of the Necks, and an avid reader of both Zuel's and Shand's articles and reviews, which I find consistently reliable, wellinformed, considered and colourfully written, this seemed an ideal way to match up both practitioners and critics of music.

'Dancing about architecture' is not, of course, as impossible or unlikely as it may sound: in fact many dance works have been conceived of as relating directly to the built environment. The English jazz writer Paul Savage, describing the music of John Coltrane, refers to 'a musical monument like that feat of terpsichorean architecture Giant Steps' (2000). In a 2004 issue of the Architectural Review entitled 'Terpsichore and the Architects,' Simon Goldhill quotes choreographer Trisha Brown: 'I have a deep sense of my body’s architecture ... the skeleton.’ He notes that in ancient Greek theatre, 'the chorus danced the architecture of the theatrical space into being' and 'the dancer was a storyteller whose body told a story, like a sculpture coming alive or a mobile embodiment of tradition' (2004). Choreographer Siobhan Davies speaks of the dancer building 
an inner architecture with volume, texture and rhythm, which allows you to slice up space ... Classical ballet and classical architecture share proportion, grandeur, and the idea of being at the centre of the universe ... Light and acoustics are very important in dance and architecture: we have to consider how we introduce light to form and how we hear ourselves live in that form. (cited in Goldhill 2004)

Not only are there strong affinities between dance and architecture, in some contexts dance is architecture.

There are also strong affinities between music and architecture. In her essay 'Postmodern Architecture/Postmodern Music,' Jane Piper Clendinning argues that 'the most useful appropriations of terminology reveal tangible links in practice, technique, method, or aesthetic between the two art forms’ (2002: 119). Due to its non-verbal nature and construction of identifiable elements, 'music may be more like a building than a poem, novel, short story, or a play’ (2002: 120). Postmodern architecture and music often both involve ‘quotation and obvious allusion’ to older styles. Obvious examples in architecture are Frank Gehry’s Walt Disney Concert Hall in Downtown LA, or Michael Graves’s Portland Building in Oregon. In music one could cite Luciano Berio’s Sinfonia (1968)—which pastiches Mahler’s $2^{\text {nd }}$ Symphony, Bach, Samuel Beckett's novel L'Innomable (1953, The Unnameable), among other things—and Karlheinz Stockhausen’s Hymnen (1967)—which samples a series of electronically transformed national anthems from around the world in a kaleidoscopic, swirling global voyage. Clendinning presents two postmodern musical case studies: John Corigliano’s opera The Ghosts of Versailles (1991), with its pastiches of numerous other operas and $18^{\text {th }}$ century plays; and Ligeti's Piano Concerto (1988), which draws on previous works by Ligeti as well as 'a wide range of Western and non-Western music' (Clendinning 2002: 134).

These postmodern affinities do not take us very far in a search for direct connections between music and architecture, however. In his 2006 book Noise Orders: Jazz Improvisation and Architecture, David P. Brown, a professor of Architecture at the University of Illinois in Chicago, suggests that 'the architect may take on the role of improvisor as well as other roles involved in the making of improvised music, including those of composer, soloist, provider of rhythmic support and listener’ (2006: xvi). He finds affinities between Mondrian’s ‘neo-plasticism’ and the open form of boogiewoogie, John Cage and Rahsaan Roland Kirk and physicality, temporalities in 
Louis Armstrong and le Corbusier, and the work of the Association for the advancement of Creative Musicians (AACM) and that of Mies van der Rohe. His argument is that improvised music can influence architecture in terms of suggesting more open forms of practice in which architects can contribute to emerging environments rather than predetermined ones. Apart from influencing alternative forms of architecture, improvised music could influence architectural practices in creating more dynamic urban environments. Heavily conceptual in its focus, the book nonetheless explores the creative potential of 'improvised architecture.'

The brief for the symposium was to address issues of writing about music in different contexts: this produced writing on a wide array of different subjects, from travelogue to film music, European art music, African-American music, and rock music. Keynote speaker Hollis Taylor's multimedia performance 'Post Impressions: Music Writing as Bent Travelogue' is difficult to reproduce as a simple piece of 'writing,' although it combines experimental music writing by a music practitioner documenting a musical event with diary entries and photographs. It operates more as a piece of creative nonfiction in which the music performed on the project in question, Great Fences of Australia, released as a CD and DVD in 2007, plays an important part. On the page, it is more a kind of 'nomadic writing' in the tradition of works such as Stephen Muecke's No Road (1997) or Reading the Country (1984), which engage with Aboriginal forms of mapping Australia. Taylor's concluding thoughts about the outback Australia whose fence-lines she and her partner Jon Rose bowed into being like Aeolian harps, invoke the Aboriginal songlines that form networks across the country: 'It sets me reflecting on how it might have been here when every feature of the landscape was woven into song. This land was a giant travel book ... a historybook ... a natural science book. The great Australian songbook stretched back and forward in time.'

References to Berlin in Post-Impressions are writ large in Andrew Hurley's 'Collapsing (New) Buildings: Town Planning, History and Music in Hubertus Siegert’s Berlin Babylon (2001).' Some of the music in question is provided by German experimental noise merchants Einsturzende Neubaten, sometime associates of Nick Cave. Siegert's documentary is an account of the hasty, manic reconstruction of Berlin in the 1990s, but is also about history, invoking Walter Benjamin’s famous 1940 'Angel of History’ (2009). Musical history plays a part in the film, with snippets of Beethoven, Wagner, 
Brahms and Bertolt Brecht's collaborator Hanns Eisler, but Hurley gives particular emphasis to a $78 \mathrm{rpm}$ recording of Beethoven's $9^{\text {th }}$ Symphony conducted by Hans Knappertsbusch in 1934, the year after Hitler's rise to power. Einsturzende Neubaten's engagement with architecture, which involves the use of miscellaneous junk collected from local tips wherever they perform, is especially grounded in the Berlin squatters' movement of the 1980s, and the band's own habit of playing in historically significant deserted spaces in the city. There is also direct reference to architecture in the lyrics of their two tracks incorporated into the film, which mourn the city's 'superficial face-lift' and the subsequent loss of whole areas of the city that were full of memory and history. Einsturzende Neubaten’s ‘dance about architecture’ is a particularly regretful one.

My own historic experience of Einsturzende Neubaten in performance took place in 1991 at the cavernous, three-tiered Phoenician Club on Broadway, formerly a cinema and television studio, and later a discotheque that featured Australian groups such as Sherbert and AC/DC in the 1970s. Situated just up the road from UTS, the venue was blitzed by Einsturzende Neubaten with supermarket trolleys, poles and other noisemaking devices. Local 'underground' audiences_one of whom was dressed as a Nick Cave clone-celebrated both their European avant-garde status and their Berlin connections with Nick Cave and the Bad Seeds. Later in the 1990s the Phoenician Club became a venue for dance parties, and in 1995 the notorious Anna Wood episode took place, in which the teenager died from ecstasy-related cerebral oedema, which eventually led to the club’s closure in 1998 (see Homan 1998). So probably without knowing it, Einsturzende Neubaten also performed in an historically significant and now defunct building in Sydney.

In 'Is the Unspeakable Singable? The Ethics of Holocaust Representation and the Reception of Górecki’s Symphony no.3,' Alison Moore confronts the dilemma of writing about music that becomes related to the Holocaust. The extremely popular, mournful music of the 1976 'Symphony of Sorrowful Songs,' by Polish composer Henryk Górecki, who died in November 2010, has become what Moore describes as 'one of the most commercially successful pieces of classical art music in its time.' It subsequently became the subject of a 2008 film by British documentary maker Tony Palmer, more noted for his work about the Beatles, and other films that have attempted to connect it visually with the Holocaust. Górecki was a relatively obscure figure until 
1992, and only became well known internationally when an Elektra-Nonesuch recording of the symphony with soprano Dawn Upshaw, released in commemoration of the Holocaust, sold more than a million copies. This recording went to no. 3 on the British pop charts in February 1993, outranking Madonna, and remained on Billboard's classical charts for 134 weeks (Howard 2002: 195).

Sydney Conservatorium graduate Luke Howard wrote his $\mathrm{PhD}$ dissertation on the history and reception of Górecki’s $3^{\text {rd }}$ symphony at the University of Michigan in 1997, and published 'Production vs. Reception in Postmodernism, the Górecki Case' in 2002. There he recounts that rumours circulated after the success of the work that it had been suppressed by the Communist authorities until after the fall of the Berlin Wall, and that this was its first recording. In fact it was first performed in Royan in France in 1977, and on several other occasions in the 1970s, and first recorded in Poland in 1980, and on a number of subsequent releases. At the Royan performance, it was panned by Western critics, and one composer (possibly Pierre Boulez), is reported to have cried 'Merde!' as it ended. British industrial group Test Department included excerpts from it on a tour in 1985-86, and it was used in the soundtrack to Maurice Pialat's 1985 film Police, starring Gérard Depardieu. The first British performances took place in 1987 and 1988. This was long before the symphony was incorporated into the soundtracks of Hollywood films like Peter Weir’s Fearless (1993) and Julian Schnabel’s Basquiat (1996) (Howard 2002: 196).

Although Górecki explicitly denied that the work references the holocaust, the association has remained, partly because a section of it relates to World War II. As a result, the work joins by association a small group of compositions that do reference the Holocaust-namely Schoenberg's A Survivor from Warsaw (1947) and Steve Reich's 1988 Grammy Award-winning experimental work for string quartet and tape, Different Trains. Górecki’s compatriot Krzysztof Penderecki composed Dies Irae in 1967 for the unveiling of the Polish government war memorial at Auschwitz, after Górecki had withdrawn from the commission only months earlier, considering himself incapable of the task. Górecki’s 'spiritual minimalist' musical style has something in common with Reich, but it is in other respects a conventional work, and its association with the Holocaust remains dubious. According to Alex Ross, Górecki, along with John Taverner and Arvo Pärt, belongs to a trio of twentieth century composers 'who achieved 
a degree of mass appeal during the global economic booms of the eighties and nineties; they provided oases of repose in a technologically-oversaturated culture' (Ross 2009: 578-579 ). Rather maudlin and lugubrious repose in Górecki’s case.

Excerpts from Górecki’s Third Symphony were 'cannibalised' in a series of different contexts in the 1990s by British elecronica artists. Lamb used excerpts in a track entitled 'Górecki' (1997), and Goldie incorporated it into his 60 minute track 'Mother' (1998), after Björk had famously introduced him to the work. Both pieces remove the symphony from any Holocaust associations and take it into strongly personalised territory. It was also sampled by Norwegian goth-metal band Ildfrost in 1993, in what Howard calls 'blank eclecticism,' and by experimental Krautrock band Faust in 1994 in 'a tightly constructed anti-fascist statement' (Howard 2002: 197). US rock group Smashing Pumpkins used it as pre-concert music on their 1996 world tour, and when things got out of hand in the mosh-pit in Auckland, it was used to try and calm people down - one of many instances of the use of classical music to defuse disruptive youth. The symphony was sampled almost imperceptibly in British rock group the Pale Saints' 1994 track 'Henry,' and in Bristol trip hop musician Tricky’s remix of Smashing Pumpkins’ 1996 track 'Milk.' And so on. In retrospect, Howard’s argument that these accumulated appropriations amount to a definably postmodern 'breach between "high art” and mass culture,' which involved 'the collective consumer, not the composer, who crossed traditional boundaries in listening and responding to the recording of the symphony’ (Howard 2002: 203), seems rather thin. Obviously the lugubrious mood of the symphony attracted these British musicians who were working in a genre noted for its melancholia. Moore suggests the work is 'heavily imbued with Catholic pathos and redemption, and ... arguably encourages a collapsing of the listener's own emotional pain into an identification with the suffering of war victims.' This corresponds to what she calls 'écouteurism,' a sonic version of 'voyeurism.'

'From Gospel to Gates: Modal Blending in African-American Musical Discourse before the Signifyin(g) Monkey,' by Chris Coady, demonstrates the importance of interdisciplinary, collaborative work on Gospel music done prior to the 1988 publication of Henry Louis Gates's key work The Signifyin( $g$ ) Monkey: A Theory of AfricanAmerican Literary Criticism. Gates, who recently appeared on Australian television screens on the SBS channel as an interviewee in the five-part program America: The 
Story of the US (2010), has long been acknowledged as a pioneer in the representation of African-American cultural forms as signifying practices. Again postmodernism has tended to obscure Gates’s work: as Russell A. Potter noted in his 1995 book about US hip hop, Spectacular Vernaculars, Gates’s theorisation of a single African-American vernacular risks essentialising a diversity of overlapping and sometimes contradictory vernaculars (1995: 17). Nonetheless,

\footnotetext{
the practice of Signifyin $(\mathrm{g})$, which Gates demonstrates compellingly lies at the heart of much vernacular American language and art, is a theoretical practice which is fundamentally ironic, fundamentally postmodern. Signifyin(g), briefly put, is both the trope of pastiche and a pastiche of tropes, and its most central trope is that of the sly exchange of the literal for the figurative, and hip hop is its most profound and lively incarnation (Potter 1995: 18).
}

Again, hindsight breeds scepticism, and the influence of the signifying monkey on hip hop now seems tenuous, despite early examples such as Schooly D’s 1988 track 'Signifyin’ Rapper.' Coady argues that the 'modal blending' of linguistic and musical analysis that Gates uses had its antecedents in documentations of African-American Gospel music in the decades before The Signifyin( $g$ ) Monkey.

John Encarnacao’s ‘Musical Structure as Narrative in Rock’ presents musicological analyses of several examples of rock music, drawing on Susan McClary's notion of a 'quest narrative,' and the assumption that rock music is itself a form of writing. Using the term 'sound mass' to denote the overall identity of a song in terms of timbre, dynamics, density and register, Encarnacao analyses a series of musical examplesincluding Elvis Costello’s 'Welcome to the Working Week' (1977)—which convey a quest narrative. He also presents examples of non-narrative rock song structures, from Pink Floyd to Animal Collective, suggesting that more recent exponents of unconventional song structure such as the US avant-folk and new psychedelic movements are embracing 'labyrinth, immersive and single-cell' structures that are analagous to those of Western art music composers of the period 1920-1970.

Sarah Attfield's 'Punk Rock and the Value of Auto-ethnographic Writing about Music' examines the importance of writing on music from the perspective of performers and fans, rather than critics. Drawing on the work of prominent Australian historian Greg Dening, Attfield charts the recent increase in auto-ethnography in music studies, as well as signalling some of its perils and pitfalls. She also refers to writers who combine an academic perspective with a fan's involvement in the music - in this case British 
punk - and use personal narrative, such as Simon Reynolds, Helen Reddington, Nils Stevenson and Roger Sabin, but values above all writers who are able to describe subcultural music scenes at first hand.

Dean Biron examines liner notes, a form of music writing often overlooked, arguing that music, dance, architecture and other art forms all feed off and provide nourishment for one another. After presenting a brief history of the record sleeve, drawing on Elborough's exhaustive The Long-Player Goodbye: The Album from Vinyl to iPod and Back Again (2008), and of music writing as literature, using Peter Dayan’s Music Writing Literature: From Sand via Debussy to Derrida (2006), Biron goes on to analyse examples of a genre of writing that arguably has no rules. From Bob Dylan's inchoate poetry to the Beach Boys' fan letters, from didactic salvoes to downright commercial propaganda (buy this record!), liner notes are a form of publicity that can occasionally be helpful (or too helpful, as in the often detailed analyses on the 'container inserts' of classical CDs, which often need a magnifying glass to read), are sometimes woefully self-indulgent ('I first heard this band on my car radio with my girlfriend in 1967'), or often wilfully irrelevant (as when Stockhausen provides a detailed description of everything he ate on the day of recording and says nothing about the music).

Biron divides liner notes into five different categories - literary, as in Dylan's poetry; tangential—as in US folk guitarist John Fahey's bizarre shaggy dog stories that filled entire LP covers on his own label Takoma in the 1970s; expository—usually written by the composer recounting the evolution of the work; propagandist-political as well as commercial, as in John Zorn's pro-Jewish sentiments; and retrospective- usually pertaining to compilations of music from the distant past, as in Neil Young's endless personal archive recordings, which really challenge the fan's endurance. Ultimately, liner notes demonstrate that music and writing belong together, like dance and architecture, and writing about music 'is a valuable part of the overall experience of interacting with recorded music.' The insidious rise of mp3s has all but obliterated liner notes, which have nonetheless come into their own with the increasing quantity of CD reissues.

Becky Shepherd uses the term 'mouldy modernists,' which derives from the modernist jazz term 'moldy fig' —an ardent admirer of old fashioned styles of early jazz- to describe the apparent attachment of specialist rock critics to canonical music of the 
1960s and 1970s. CD reissues arguably play a large part in this, with most popular music magazines devoting a lot of space to re-evaluations of canonical items. The longawaited release of 'Re-Mastered and Enhanced' editions of the entire back catalogue of the Beatles, which caused a media feeding frenzy in 2009, is the most prominent example of this. The growing popularity of pastiched retro forms of music such as psychedelia, folk, disco and 'classic rock' by contemporary bands is another. In a study of 'best of' polls in the most prominent rock music magazines in the US and UK (SPIN, Rolling Stone, MOJO, Q and Classic Rock), Shepherd finds that 88 percent of recordings listed were released prior to 1980 . She attributes this to a form of imaginary nostalgia, or nostalgia without memory-Frederik Jameson’s ‘imaginary museum’ (1991). As a result, '[t]he world of sampling, remixes, mash-ups and the explosion of mp3 cultures and home production' is being overlooked in print outlets, or relegated to more specialist on-line publications, blogs and forums. In Australia, for example, online magazines such as Mess + Noise and Cyclic Defrost are providing far more contemporary accounts of musical developments both here and elsewhere, while Rolling Stone struggles to keep up in print form. In one sense, the excessive nostalgia that Shepherd diagnoses is due to the ageing of prominent US rock critics such as Robert Christgau (born in 1942), self-styled 'dean of American rock critics,' who used to give 'marks' to recordings in his reviews, and Greil Marcus (born in 1945) with his ongoing obsession with Bob Dylan, and a 'new' book on Van Morrison (2010). Both continue to hold patriarchal court at the annual Experience Music Project (EMP) conferences, and maintain a long-standing association with the New York Village Voice and the US Rolling Stone. They also continue to refer to 'rock \& roll,' as if nothing had changed in rock music since the 1950s. Their readership has aged with them.

Finally, John Scannell deals with similar territory in a different way in 'Working to Design: The Self-Perpetuating Ideology of Rock.' He takes his impetus from a 2009 article on rock criticism by UK Guardian writer John Harris, entitled, appropriately enough, 'Don’t Look Back,' after the documentary about Bob Dylan’s 1965 British tour. Harris laments the decline of the 'lofty' standards of rock journalism set by 1970s figures such as Lester Bangs, Nick Kent and Greil Marcus. New Musical Express (NME) journalist Kent was noted for his heroin addiction and keeping company with rock stars with similar afflictions. His NME colleague Julie Burchill has said of him: 'rumour has it that Keith Richards was once copiously sick on his jacket after a 
prolonged smack binge and Kent never washed it again’ (2010). In his ‘1970s memoir' Apathy for the Devil, in which he recounts, among other things, his religious conversion, Kent describes himself as 'the Zeitgeist-surfing dark prince of Seventies rock journalism.' Burchill is suitably scathing: 'Cliché is piled upon cliché with all the heavy-handed ill-judgment of a manic monkey constructing a monstrous pousse-café' (Burchill 2010). Kent was once similarly scathing about academic music writer Simon Frith, suggesting he never 'got his hands dirty' and stayed at home listening to CDs rather than leaping into the sordid fray of rock star lifestyles.

Part of the problem here, Scannell suggests, is that "most music writers simply "write" as they understand it, rather than, as Deleuze and Guattari might say, pursue a becoming-music through the writing process.' This would involve 'the production of sensation equivalent to the affective power of the music that inspired it in the first place.' I'm sure we’ve all had musical epiphanies generated by sensations produced by reading reviews or accounts of concerts, albums and the like, but now, more often than not, this fails to happen. As a Dylanologist, like Marcus, and also a Deleuzian, Scannell focuses on Todd Haynes's Dylan film ‘biography’ I'm Not There (2007), a distinctly non-representational account of episodes from Dylan's life that he sets alongside Dylan’s own account of 'faulty memory,' Chronicles: Volume One (2004). In both cases, writing is seen as the 'pursuit of difference,' which has broader concerns than simply reaching an existing audience. This links up with Sarah Attfield's valuing of writing about music by practitioners and scenesters rather than critics.

On the other hand, much rock journalism tends to trade in clichés, assess a musician solely in terms of his or her career, and simply contextualise any new album or concert appearance in terms of career development. This is one reason why there are so many 'quickie’ biographies of the more prominent pop and rock musicians, usually constructed from a detritus of press clippings. Scannell refers to this as 'writing to design,' and although recent (auto)biographies like Life (2010) by Keith Richard (born 1943), surely the ultimate example of the 'rock and roll outlaw' cliché, may stimulate the gossip-hungry, and more media feeding frenzies, does it really offer anything more than what is by now third-hand gossip? Another example of journalistic clichés that Scannell provides is the appellation 'the new Bob Dylan,' which has been applied by various journalists to an alarmingly wide range of musicians, and apart from betraying a 
lack of imagination, amounts simply to a 'pursuit of homogeneity.' Examples of ‘writing as becoming' are seen by Scannell (and Harris) in Marcus’s 1989 Lipstick Traces, which idolises the obnoxious John Lydon, surely one of the most boorishly reactionary of punk figures, in terms of a 'secret history' involving the Dadaists, the Situationists, Paris 1968, and a 16th century Anabaptist revolt led by John of Leydon. Fanciful, yes. Convincing, no.

There will always be debates about music writing and its value. Recently I reviewed Robert Milliken's biography Mother of Rock: The Lillian Roxon Story, the reissue of which coincided with a documentary about Roxon, an almost forgotten Australian rock journalist who compiled the first Encyclopedia of Rock in New York in 1969 and died in 1973. A legendary figure in her lifetime, she held court at the round table in Max's Kansas City in New York with the likes of Iggy Pop, Alice Cooper, and Andy Warhol’s coterie, where she once publicly vilified Germaine Greer. Greer nonetheless dedicated The Female Eunuch (1970) to her, and at the launch of Paul Clarke's documentary on Roxon, also called Mother of Rock — for reasons which seem obscure-at the Melbourne Film Festival in 2010, indicated that all she ever wanted was for Roxon to like her. Obviously a tall poppy who never received the acclaim (or opprobrium) of Greer, Robert Hughes, Clive James and their ilk, Roxon is now being rehabilitated. But her music writing does not stand the test of time - clichéd, breathless, and US-centric, her main achievement seems to have been as a gossip merchant who, after stints in the Brisbane literary scene of the 1950s and the Sydney push, successfully penetrated the notoriously snobbish hegemony of the New York music scene in the 1960s, and led something of a charmed life style until asthma destroyed her. Her weekly missives from New York to the Sydney Morning Herald were lapped up by a readership obviously prepared to kow-tow to whatever was happening in the Big Apple. Her famous front page report about the protest march of 'the women's liberation ladies' in 1970- ‘this isn't a fad like the hula hoop'-is more about herself than any of the issues that were at stake.

Ultimately, all that lies beneath Costello's_or Mull's — apothegm is surely resentment of the over-inflatedly powerful and unjustified influence of inflated exponents of music journalism on an often gullible readership. But at its best, as in the case of most of Simon Frith's work, along with that of numerous others, writing about music makes us 
think about why it matters, why it is worth taking seriously, and why committing to it as a life-long project is important and worthwhile. And why, as in Miss Smilla's case, it can even become a matter of life and death.

\section{Reference List}

America, the Story of the US. 2010, Television series, Nutopia Productions, History Channel. Beckett, S. 1953, L'Innomable. Les Éditions de Minuit, Paris.

Benjamin, W. 2009 (1940), On the Concept of History. CreateSpace, no place.

Burchill, J. 2010, 'Apathy For the Devil: A 1970s Memoir by Nick Kent,' book review, The Observer, 7 March. Online, available: http://www.guardian.co.uk/books/2010/mar/07/apathy-for-devil-bookreview [Accessed 23 Feb. 2011].

Botts, L. 1981, Loose Talk: The Book of Quotes from the Pages of Rolling Stone Magazine. Penguin, New York.

Brackett, D. 2000, Interpreting Popular Music. University of California Press, Berkeley.

Brown, D. P. 2006, Noise Orders: Jazz Improvisation and Architecture. University of Minnesota Press, Minneapolis.

Burchill, J. 2010, Review of Apathy For the Devil: A 1970s Memoir by Nick Kent, The Observer, 7 March. http://www.guardian.co.uk/books/2010/mar/07/apathy-for-devil-book-review [accessed 12 Sept. 2011].

Carmody, J. 2011, 'Man about Town Shares His Passion in a Mixed Medley.' Sydney Morning Herald March 26-27: 30.

Clarke, P. (dir.) 2010, Mother of Rock Lillian Roxon, documentary, Lowlands Media.

Dayan, P. 2006, Music Writing Literature: From Sand via Debussy to Derrida. Ashgate. Burlington, VT.

Dylan, B. 2004, Chronicles: Volume One. Simon \& Schuster, New York.

Elborough, T. 2008, The Long-Player Goodbye: The Album from Vinyl to iPod and Back Again. Sceptre, London.

Gates, H. L. 1988, The Signifying Monkey: A Theory of African-American Literary Criticism. Oxford University Press, New York.

Goldhill, S. 2004, 'Terpsichore and the Architects.' Architectural Review, vol. 216, August, 81-90.

Griffiths, D. 2008, Elvis Costello. Indiana University Press, Bloomington.

Hoeg, P. 2005, Miss Smilla’s Feeling for Snow. Panther, London.

Homan, S. 1998, 'After the Law: The Phoenician Club, the Premier, and the Death of Anna Wood.' Perfect Beat, vol. 4, no. 1, July: 56-83.

Howard, L. 2002, 'Production vs. Reception in Postmodernism, the Górecki Case,' in Postmodern Music/Postmodern Thought, (eds) J. Lochhead \& J. H. Auner. Routledge, New York \& London, 195-206.

Goldhill, S. 2004, 'Terpsichore and the Architects.' Architectural Review, vol. 216, August, 81-90. Online, available: http://findarticles.com/p/articles/mi_m3575/is_1290_216/ai_n6212588/ [accessed 23 Feb. 2011].

Greer, G. 1970. The Female Eunuch. Paladin, London.

Harris, J. 2009, 'Don’t Look Back,' The Guardian Online, 27 June. Online, available: http://www.guardian.co.uk/music/2009/jun/27/music-writing-bangs-marcus [Accessed 16 June 2010].

Haynes, T. (dir.) 2007, I’m Not There, motion picture, Killer Films.

Howard, L. 2002, 'Production vs. Reception in Postmodernism, the Górecki Case,' in Postmodern Music/Postmodern Thought, (eds) J. Lochhead \& J. Auner, Routledge, New York and London, 195-206.

Jameson, F. 1991, Postmodernism, or, The Cultural Logic of Late Capitalism. Duke University Press, Durham, NC, \& London.

Kent, N. 2010, Apathy For the Devil. Faber \& Faber, London.

Marcus, G. 1990, Lipstick Traces: A Secret History of the Twentieth Century. Harvard University Press, Harvard. 2010, Listening to Van Morrison, London: Faber \& Faber.

Milliken, R. 2010, Mother of Rock: The Lillian Roxon Story. Revised Edition. Black Inc, Melbourne. 
Muecke, S., with K. Benterrak and P. Roe 1984, Reading the Country. Fremantle Arts Centre Press, Fremantle.

1997, No Road (Bitumen All the Way). Fremantle Arts Centre Press, Fremantle.

Pialat, M. (dir.) 1985, Police, Emmanuel Schlumberger Productions.

Potter, Russell A. 1995, Spectacular Vernaculars: Hip-Hop and the Politics of Postmodernism. State University of New York Press, Albany.

Richards, K. 2010, Life. Little, Brown and Company, London.

Ross, A. 2009, The Rest is Noise: Listening to the Twentieth Century. Harper Perennial, London. 2010, Listen to This. Fourth Estate, London.

Roxon, L. 1969, Lillian Roxson's Rock Encyclpoedia. Grosset \& Dunlap, New York.

Savage, P. 2000, 'Perfect Blend of Sound, Composition and Improvisation.' Review of Coltrane Jazz, Amazon.com. Online, available: http://www.amazon.com/Coltrane-Jazz-John/productreviews/B003XKAZUE [accessed 23 February 2011].

Schnabel, J. 1996, Basquiat, motion picture, Eleventh Street Production.

Siegert, H. 2001, Berlin Babylon, documentary, Philip-Gröning-Filmproduktion.

Weir, P. (dir.) 1993, Fearless, motion picture, Spring Creek Productions/Warner Brothers.

White, T. 1983, ‘A Man Out Of Time Beats the Clock: An Interview with Elvis Costello.’ Musician, no. 60: 44-53. 